\title{
A unique venue of discoveries in structural chemistry and structural biology: the 75-year and 60-year jubilees of the MRC Laboratory of Molecular Biology—a personal tribute
}

\author{
Istvan Hargittai ${ }^{1} \cdot$ Magdolna Hargittai $^{1}$ \\ Accepted: 7 September 2021 / Published online: 28 September 2021 \\ (c) The Author(s) 2021
}

\begin{abstract}
In 1962, the MRC Laboratory of Molecular Biology in Cambridge, UK, moved into a new building and continued a success story that had begun 15 before. Milestone discoveries and Nobel Prizes have followed ever since. They have led to profound changes in our basic ideas about the nature of life and the way medicine operates. Structural chemistry has paved the way for this unprecedented progress.
\end{abstract}

Keywords Laboratory of Molecular Biology $\cdot$ Structural biology $\cdot$ Helix structures $\cdot$ W. Lawrence Bragg $\cdot J$. Desmond Bernal $\cdot$ Max Perutz $\cdot$ Watson and Crick $\cdot$ Richard Henderson

The Cavendish Laboratory in the English Cambridge was a center of modern physics in the 1920s and 1930s. When its leader, Ernest Rutherford, died in 1937, W. Lawrence Bragg became his successor. Soon World War II interrupted peaceful research and when it was over, Bragg was faced with the big decision about the future of the Cavendish Laboratory. It might have been natural for him to continue in atomic physics as its main emphasis. However, it would have been difficult to expect it to stay a leader, because atomic physics had become huge, and especially in the United States, during the war. Bragg was a physics Nobel laureate, but his award was for contributions to a very different field, X-ray crystallography. Thus, instead of fighting "a rearguard action" in atomic physics, he had a stroke of genius, and opted for entering - no, not quite-rather, creating a new area of inquiry, the structural studies of biologically important large molecules. In addition, he opened the Cavendish to another pioneering area, radio astronomy, which became also hugely successful.

Dedicated with thanks and appreciation to Richard Henderson.

Istvan Hargittai

stuceditor@gmail.com

Magdolna Hargittai

hargittaim@gmail.com

1 Budapest University of Technology and Economics, Budapest 1521, Hungary
The project of structural studies was an especially risky direction to take, because there was still a debate going on at the time whether or not such giant molecules existed in the first place. Furthermore, the determination of their structure was rather a dream than a certainty. There were at least three ingredients that lent promise to his decision although we cannot know if he considered all when he decided. There were the early successes in using X-ray diffraction in the investigation of fibrous materials, first by Michael Polanyi in the 1920s in Berlin and then by William Astbury in Leeds. Another was J. Desmond Bernal's first successful experiment using X-ray diffraction of protein crystals in the mid1930s. Then, there was Max Perutz, a hard-working and enthusiastic researcher, an immigrant from Austria, who was ready and eager to start a new line of research and who would prove to be the right scientist at the right time for the task. A fourth, much needed component was the possibility of financial backing.

In 1947, W. Lawrence Bragg turned to Edward Mellanby, the Head of the British Medical Research Council (MRC), for support for the work on protein structure in the Cavendish Laboratory. Specifically, Bragg wanted to see Perutz's work put on a permanent basis. Bragg being the head of a physics laboratory, turning to the MRC may have been unusual, but, initially, it was arranged informally and efficiently. When the MRC gave its support, it was the seed of what, in 1962, became the Laboratory of Molecular Biology in a brand new building. 
The LMB celebrates its 60th anniversary in 2022, but it is a continuous story from 1947, when the MRC Unit for Research on the Molecular Structure of Biological Systems (URMSBS) was created with Max Perutz as its head. From 1962, he became the chairman of the newly established MRC Laboratory of Molecular Biology as it was moving into its new headquarters. Thus, the world of science might as well celebrate the 75th anniversary of the birth of this brilliant institution. In 2013, yet another move took place, but this, again, was a change of location and it expanded the possibilities of the LMB.

In 1962, in an unprecedented circumstance, the new institution, the MRC LMB, could boast having two Nobel Prizes and even more Nobel laureates, just at its inauguration. There have been many discoveries over the years at the LMB and the number of Nobel laureates is larger than the number of Nobel laureates in quite a number of developed countries. The number of Nobel laureates who did their prizewinning discoveries elsewhere, but have had connection of varying degrees with LMB, is also considerable. Of course, we cannot measure the significance of a research venue in the number of Nobel laureates, yet it is a telling measure of success, and its publicity value is especially high. Here we list those laureates, by the years of their awards, who did their prize-winning discoveries, or at least a significant portion of those discoveries, at the LMB or its predecessor or at Cambridge University. We add a characteristic word or two in telegraphic style as a reminder of the discoveries of the laureates listed.

1958, F. Sanger, sequencing proteins.

1962, F. Crick (Fig. 1) and J. D. Watson (Fig. 2), the double-helix structure of DNA.

1962, J. C. Kendrew and M. F. Perutz, globular protein structures.

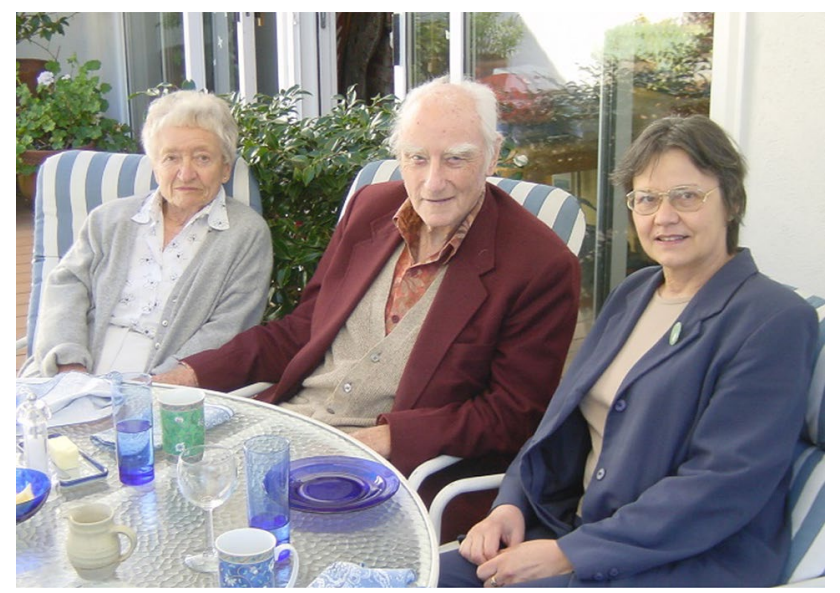

Fig. 1 Odile and Francis Crick with Magdolna Hargittai in the Cricks' home, 2004, La Jolla (photograph by and @ c the Hargittais)
1980, F. Sanger, sequencing nucleic acids.

1982, A. Klug, electron crystallography and nucleic acidprotein structures.

1984, G. J. F. Kohler and C. Milstein, monoclonal antibodies.

1997, J. Walker, mechanism of ATP synthesis.

2002, S. Brenner, H. R. Horvitz, and J. E. Sulston, genetic regulation of organ development.

2009 , V. Ramakrishnan, ribosome structure and function. 2013, M. Levitt, modeling complex chemical system.

2017, R. Henderson, electron cryo-microscopy.

2018, G. P. Winter, phage display of peptides and antibodies.

Perhaps the discovery that has received the highest visibility is the double-helix structure of DNA. It has become an icon of science. It is certainly a more peaceful symbol than the other frequent icon of what science may produce, the mushroom cloud of a nuclear explosion. Yet when Francis and Odile Crick decided to erect a helical structure above the entrance to their home, they opted for a single helix, known as the Golden Helix. Francis Crick co-authored a paper on the theoretical determination of the description of the X-ray diffraction pattern of helices [1].

The Golden Helix at the Cricks' former residence is right-handed (Fig. 3) as is DNA, but the double helix of the fence outside the pub is left-handed (Fig. 4). The handedness of the helix in the fence was a mistake by the

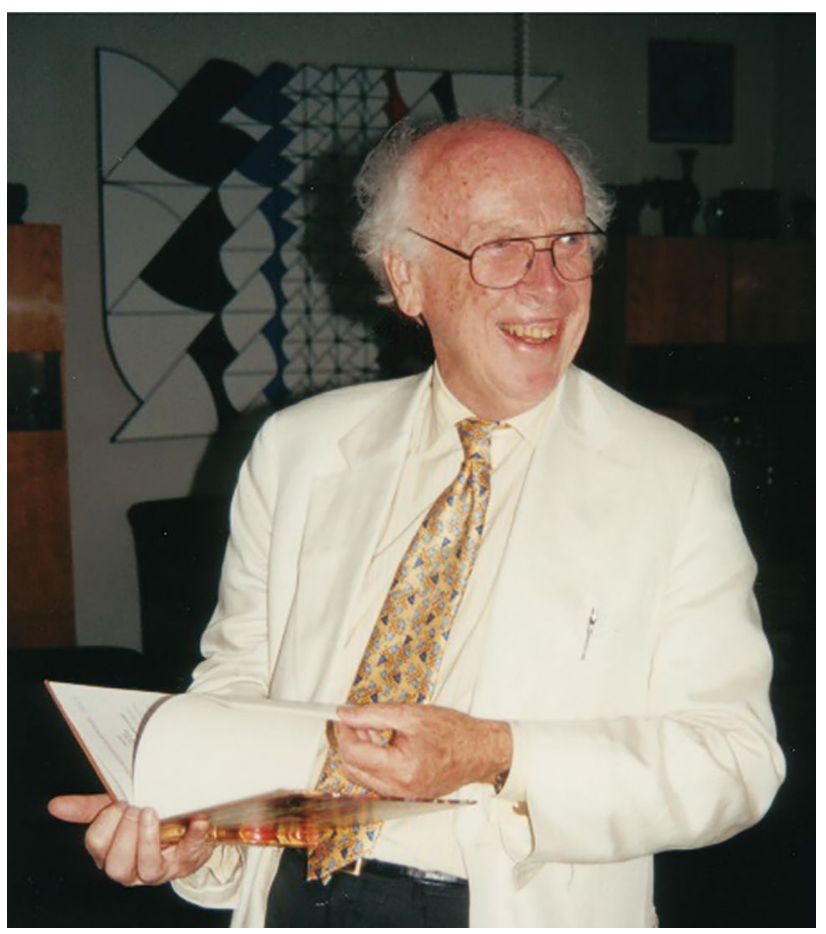

Fig. 2 James D. Watson in the Hargittais' home, 2000, Budapest (photograph by and $(C)$ the Hargittais) 


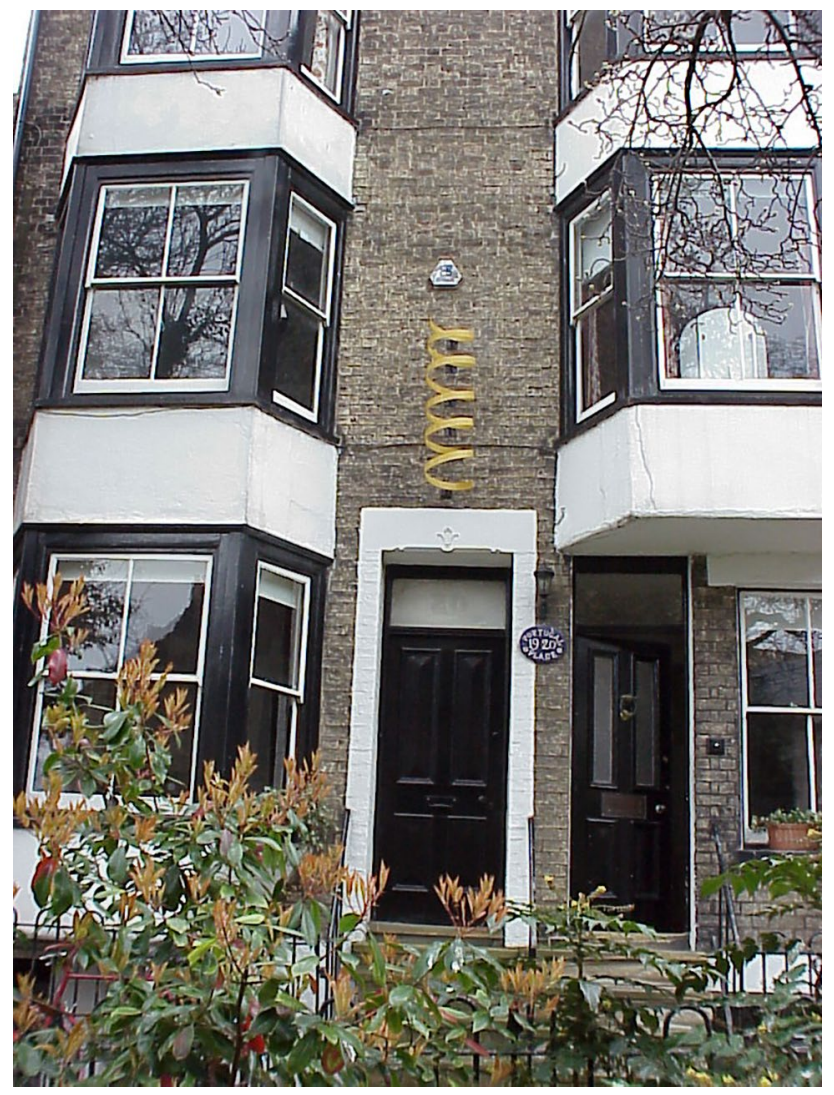

Fig. 3 Francis Crick's Golden (single) Helix above the entrance to the Cricks' former residence, 19-20 Portugal Place, Cambridge, photographed in 2000 (photograph by and (c) the Hargittais)

landlord of the pub who commissioned it after receiving the dimensions from Francis Crick, who was a regular visitor to that pub.
Model building was a crucial ingredient in the work of Crick and Watson on their road to the double helix and their helpers at the Cavendish Laboratory produced excellent models. This then continued in model building as a research tool at the LMB.

However, not everybody made use of building such models; Max Perutz (Fig. 5) was one notable exception. The model of the hemoglobin molecule, shown in Fig. 6, is a display of the overall shape of the molecule. ${ }^{1}$ Perutz (and Kendrew for myoglobin) did not opt to use models similar to Watson and Crick, because the low resolution of 5-6 angstroms did not allow an atomic model to be built, which needed to wait for higher resolution. Perutz, Kendrew, and Lawrence Bragg did try model building for protein structure around 1950. Their models were published in a famous, but wrong Proc Roy Soc paper [2]. They got it wrong because they did not understand that peptide bonds were planar, whereas Linus Pauling knew this and as a result his alphahelix and beta-sheet were correct (see more about this: [3]).

Still, the hemoglobin molecule displays beautiful symmetry in its arrangement of a tetrahedral structure. This structure did not become an icon of science and its moderate visual appeal, as compared with the double helix, may only be part of the reason. The major difference in their appeal is, in our opinion, that the structure of hemoglobin could not be correlated with its physiological function whereas the double helix suggests its role in the copying mechanism and thus in inheritance.

Perutz headed first the MRC URMSBS, then the MRC LMB, for over three decades. He left an indelible imprint on how this institution is run, that is, in a largely informal, democratic way. This is the more remarkable if considering that he grew up in a more rigid society in Austria as far as
Fig. 4 Horizontal double helix as part of the fence at a pub near the Cricks' former home, The Maypole, 20A Portugal Place, photographed in 2000 (photograph by and (C) the Hargittais)

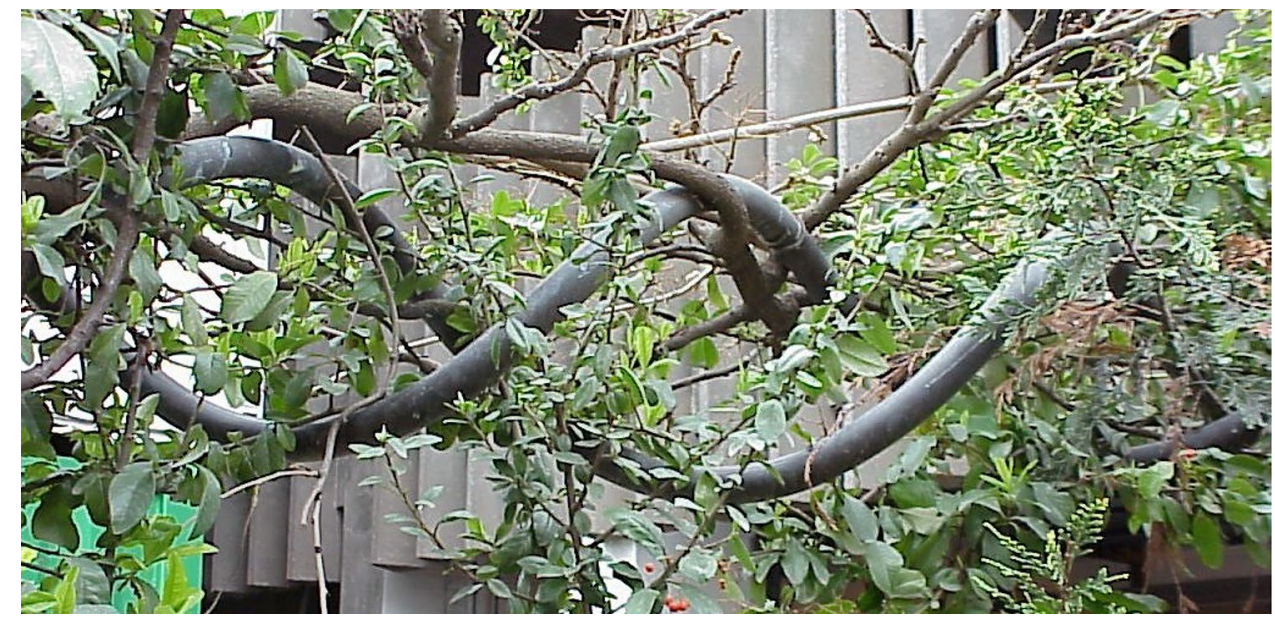

1 At the time the hemoglobin model was stored in a poorly lit room at the LMB, so, with Max Perutz's permission, we brought it out in front of the building to photograph it. 


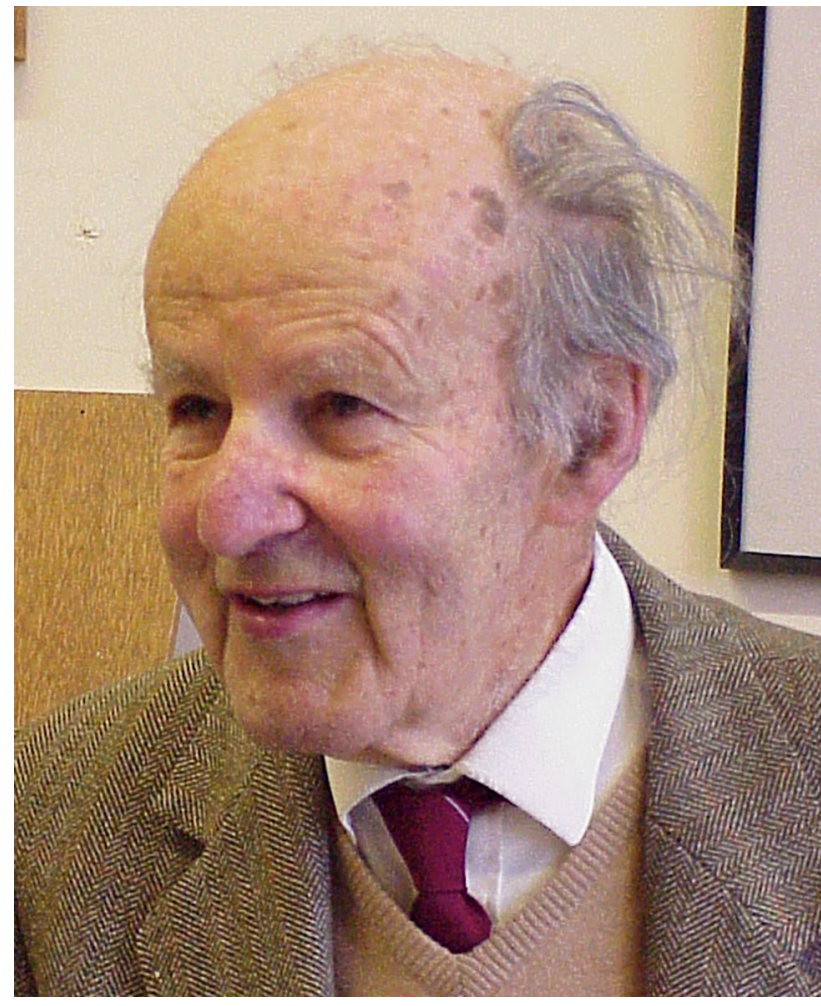

Fig. 5 Max Perutz, 2000, at the LMB (photograph by and (c) the Hargittais)

ranks and hierarchy is concerned. We hasten to add though that the Vienna of the last Habsburg era was characterized with a certain degree of informality and Gemütlichkeit. ${ }^{2}$ Perhaps, more importantly, Perutz loved the British way of life from the moment he arrived in England. The tolerance and openness at the LMB has mirrored that of British society. Suffice it to mention that four of the six directors of the LMB to date were not born in Britain; the two exceptions being Henderson and Pelham.

The MRC LMB Directors.

Max Perutz, 1962-1979 (he styled himself chairman rather than director).

Sydney Brenner, 1979-1986.

Aaron Klug, 1986-1996.

Richard Henderson, 1996-2006.

Hugh Pelham, 2006-2018.

Jan Löwe, 2018-

The creative and friendly atmosphere of the MRC LMB has been noted. When the future Nobel laureate Sidney Altman (Fig. 7) was growing up he planned to become a physicist and read a lot about science history. He dreamed

\footnotetext{
${ }^{2}$ According to a malicious characterization, rather, it was Schlamperei, meaning indolence, and sloppiness.
}

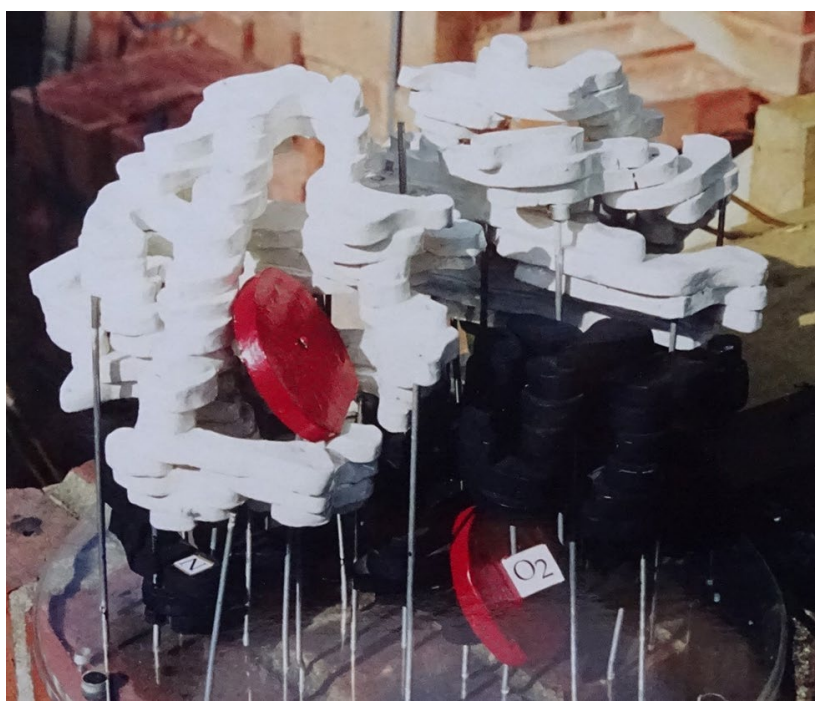

Fig. 6 The model of the hemoglobin molecule, photographed in 2000 in the open air, in front of the LMB (photograph by and (c) the Hargittais)

about venues like Copenhagen of the 1920s and 1930s. When Altman's interest was shifting toward molecular biology, he realized that the LMB in Cambridge may be in molecular biology what Niels Bohr's laboratory was for physics decades before. When he had the opportunity to do his postdoctoral studies at the LMB, his dream came true (1969-1971). He told us about his time at the LMB: "What was great about it was that there were about a dozen absolutely amazing scientists there ... [and] they set the tone for how the place worked. ... they were working every day in the lab, alongside everybody else. ... Everybody went to tea, according to the English custom, mid-morning and mid-afternoon. These «gods» of molecular biology were there, sitting with everyone at tea. They encouraged everybody to participate freely in discussion and they treated everybody equally. You could be the youngest graduate student or a technician, it didn't matter. They took your ideas seriously. They were also honest and very forthright in their criticism" [4].

Altman also received a lesson that he told us about frankly. He used a bubbler tube in an experiment and it became punctured resulting in some radioactive material scattering all over his lab space. Altman could not find the radioactive safety officer, so he turned to the lab head, Sydney Brenner, but Brenner was busy and sent Altman away. When Frederick Sanger (Fig. 8) heard about the accident, he put on rubber gloves and with a sponge and some detergent started collecting the contamination off the floor. This was a lesson of Sanger's pedagogy [5].

Genuine modesty and tremendous knowledge were Sanger's trademarks. He did not set out to solve big 


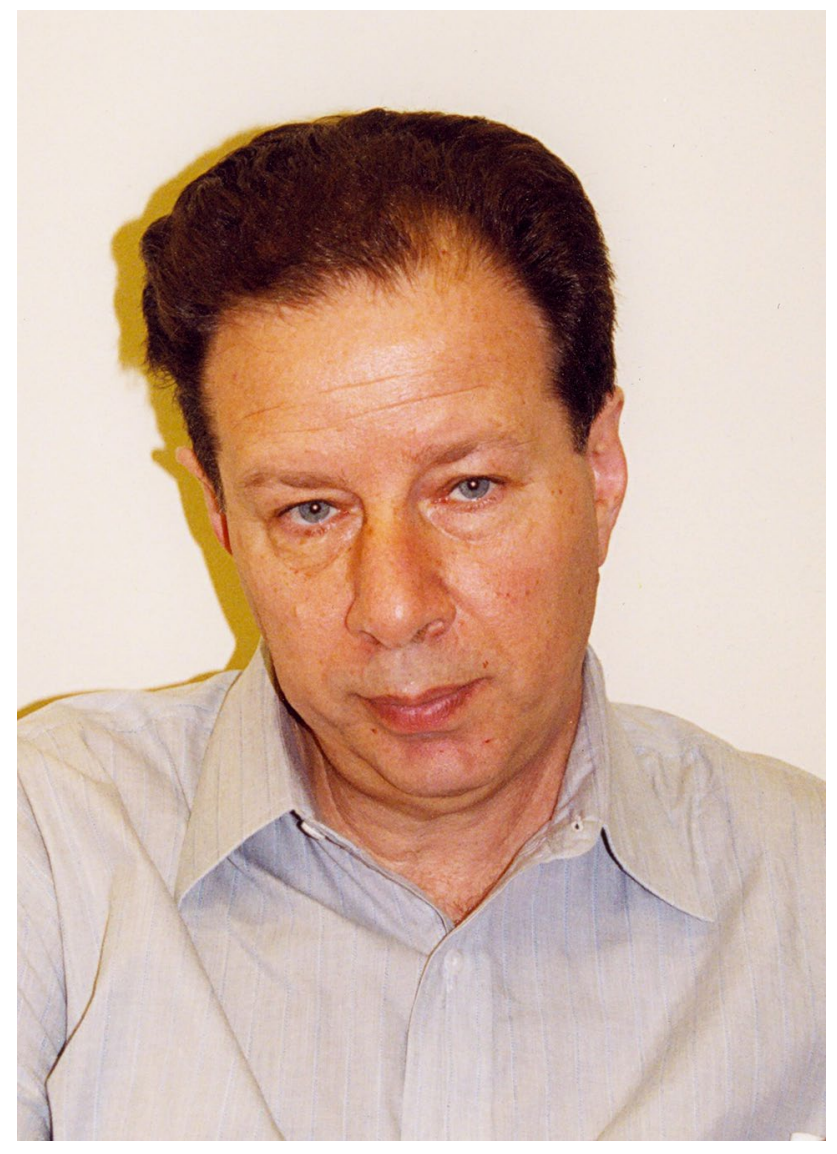

Fig. 7 Sidney Altman, 1998, in his office at Yale University (photograph by and (C) the Hargittais)

problems; they just developed in his hands to become having milestone significance. His career showed also the importance of having a good mentor for the initial impulse and of taking advantage of technological innovations. It is worthwhile to follow how Sanger's research developed in stages on his road to solve the task of sequencing proteins. When he achieved it, he went on and addressed himself to the task of sequencing nucleic acids, also progressing in a stepwise manner. Here we quote only how he described the discovery of protein sequencing.

I had got my Ph.D. with Albert Neuberger on protein metabolism. In that work I learned a lot about protein chemistry. I started off, by luck, working on proteins. I happened to get a job in 1943 with Professor A. C. Chibnall, who was the new Professor of Biochemistry in Cambridge. He suggested to me that I should try to look at the end groups of insulin, that is, at the amino acids at the end of a polypeptide chain. Chibnall was interested in the number of amino acids in proteins. Nothing was known at that time on sequencing. People had tried to do it but had not made much progress.

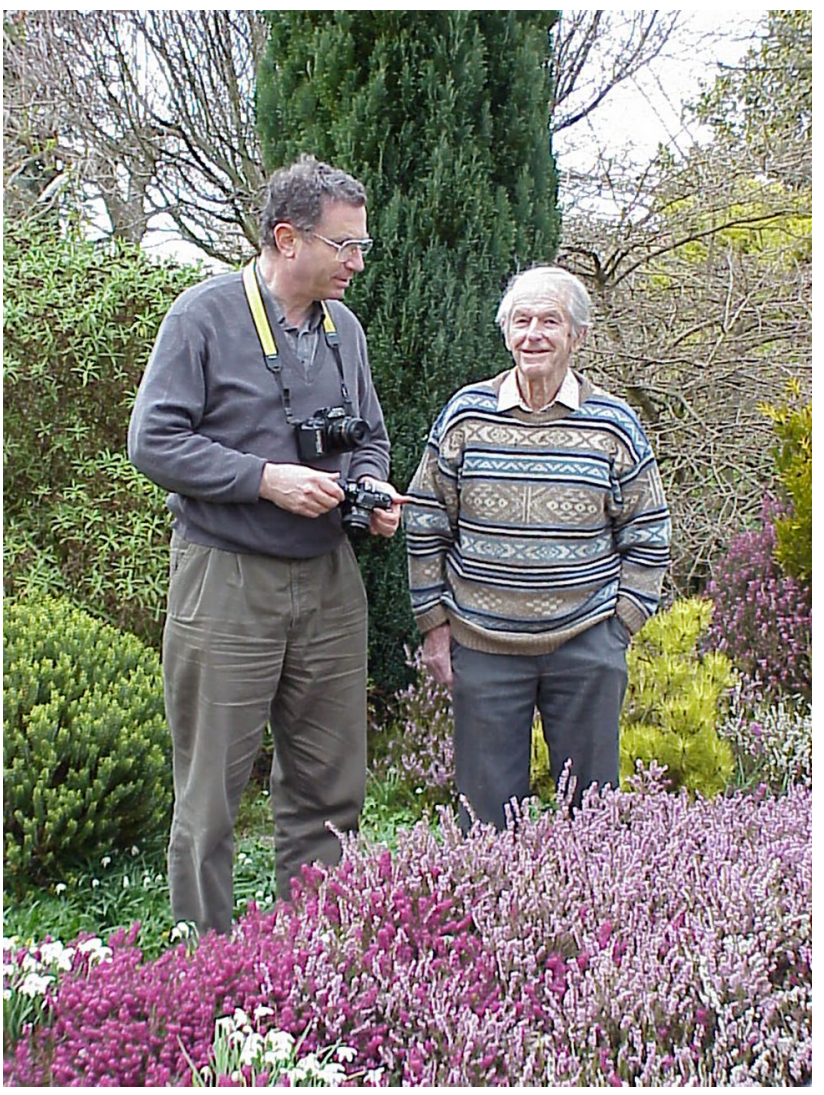

Fig. 8 Frederick Sanger with Istvan Hargittai, 2001, in the garden of the Sangers' home (photograph by and (C) the Hargittais)

I think the reason for choosing insulin was that it was a protein, probably the only one that you could buy in a pure form. Chibnall had done a lot of analysis on insulin. There was this interesting fact that it had a lot of free amino groups in it. He put me on this problem of trying to identify these amino groups. I was successful in developing a general method for looking at free amino groups. It was called the DNP method $(\mathrm{DNP}=$ dinitrophenyl). You put a colored reagent on the free amino group at the end of the chain and then you hydrolyzed the protein and identified the nature of the DNP-amino acid. The DNP was linked to the amino acid by a stable bond. The peptide bonds in the chain were broken down by acid. In this way you could identify the end groups. The main breakthrough that made this possible was due to previous work by A. J. P. Martin and R. L. M. Synge - the discovery of partition chromatography, which I applied to separating the DNP-amino acids. The work of Martin and Synge gave me the break. It was a very powerful fractionation technique. Previously crystallization and distillation were used for separating the amino acids. 


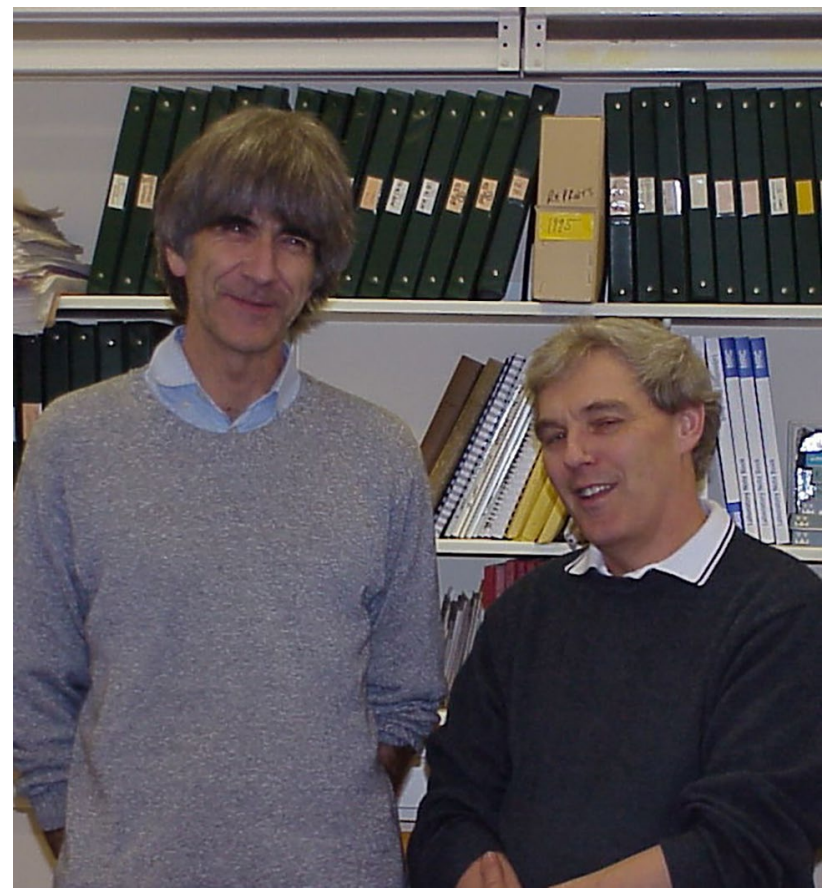

Fig. 9 Nigel Unwin and Richard Henderson, 1998, at the LMB (photograph by and (C) the Hargittais)

So, you see, I didn't set out to solve the problem of sequencing. Rather, I just set out to determine the end group and worked out a general method to do it for proteins in general. I found there were two chains in insulin. One had phenylalanine at the end, and the other had glycine at the end. One problem was that the DNP-glycine was rather unstable. When you did a complete hydrolysis, you didn't get a very good yield of the DNP-glycine, as it was broken down, so we had to cut down the time of hydrolysis. Then we found that we got a lot of other compounds produced. These turned out to be DNP-peptides. We looked at these and realized that we could get information about the sequence. With some work we could see two sequences of about four or five residues long. Those were the first sequences determined in a protein. We had the two chains of insulin and we could separate the two chains. Our next achievement was to determine the complete sequence of the phenylalanine chain, 30 amino acids long, by breaking it up into small fragments, fractionating them, and looking at their structure. We were again helped by the work of Martin and his colleagues in a new development of partition chromatography. That was paper chromatography, which enabled us to fractionate amino acids or peptides on a sheet of paper in two dimensions. Eventually we were able to put the pieces together and

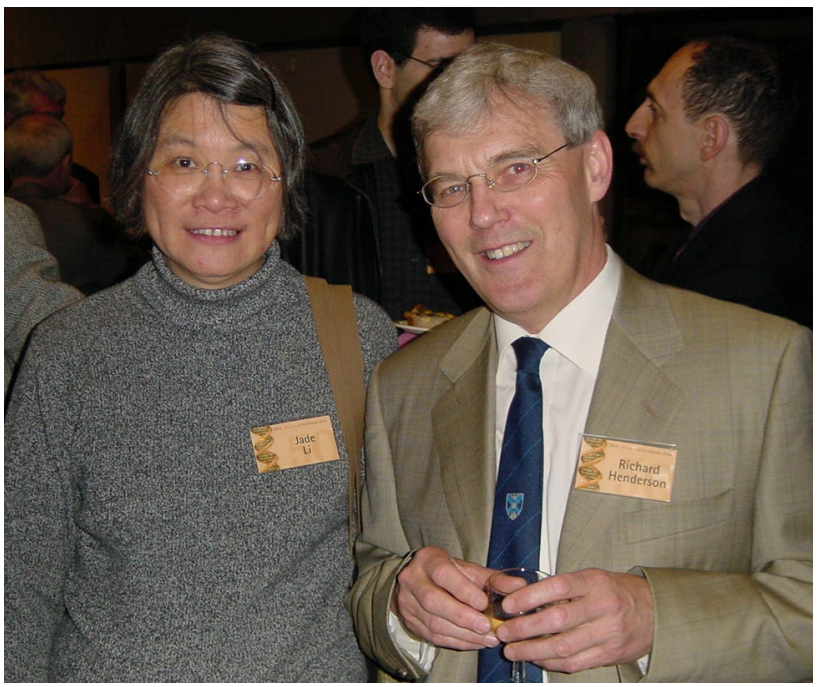

Fig. 10 Jade Li and Richard Henderson, 2003, during the 50-year jubilee celebrations at Cambridge University (photograph by and (C) the Hargittais)

determine the complete sequence. Martin and Synge were working at the time in Leeds, and Chibnall knew them well. Martin was the genius behind this. He discovered partition chromatography and went on to discover gas chromatography. He was a very inspiring person. I met him at meetings and he always had something new to talk about [6].

Above, we referred to the visiting postdoc Altman, quoting his impressions about the LMB. It is also of interest to glimpse into the mechanism of the operations through the eyes of one of its determining personalities. Richard Henderson (Figs. 9 and 10) was the director of the LMB during yet another highly successful period. His was a typical approach to commitments, but very different from the practice of many scientists in the rest of Europe. At the LMB, being the director is not the culmination of one's career; rather, it is a service to the community. When the directorship is over, he (well, so far it has been always a he) returns to being a full time researcher. Henderson was the director when we were visiting scientists at the LMB in 2000. He was always ready to talk, never gave the impression of being flooded by obligations, overexerted, over-fatigued. Of course, people used great economy in taking up his time and this was not difficult, because although everything seemed casual and informal, a well-organized support team took care of everything except some decisions that only the director could make. Referring to our usual European experience, we stress that it takes more than a well-organized support team to let a scientist even in the role of the director to deal with issues only that need his or her oversight. What is also needed is, the director to be sufficiently broad-minded and unwilling to micromanage every detail of the operations. Henderson was the opposite of a 
director who would show that without him the institution would collapse, hence his tenure should be prolonged and prolonged, again and again. Here is how Henderson saw his mandate in 1998:

My role is now to keep LMB as exciting as it has been and maintain what is a great tradition. An important part of this is keeping in touch with the previous people rather than feeling intimidated by them. To our delight, the Nobel Foundation keeps finding work at LMB that they favour.

The Lab used to be much smaller, but now [1998] about 400 people work here. There are four divisions, and the division heads decide jointly on questions of tenure with advice from outside experts and junior members of the Lab. A committee of more junior members does the original recruiting. We have a kind of federal system in which everybody has some influence and some ownership of the Lab as a place to work. It is not a communist system, but there are other ways to distribute the power. We do not have much grant proposal writing to do, we have no teaching to do, and a minimal amount of administration. I spend most of my time talking to people. Occasionally I have to write a letter. Every five years we have to do a report and submit our plans to MRC and that is time-consuming. It is strongly

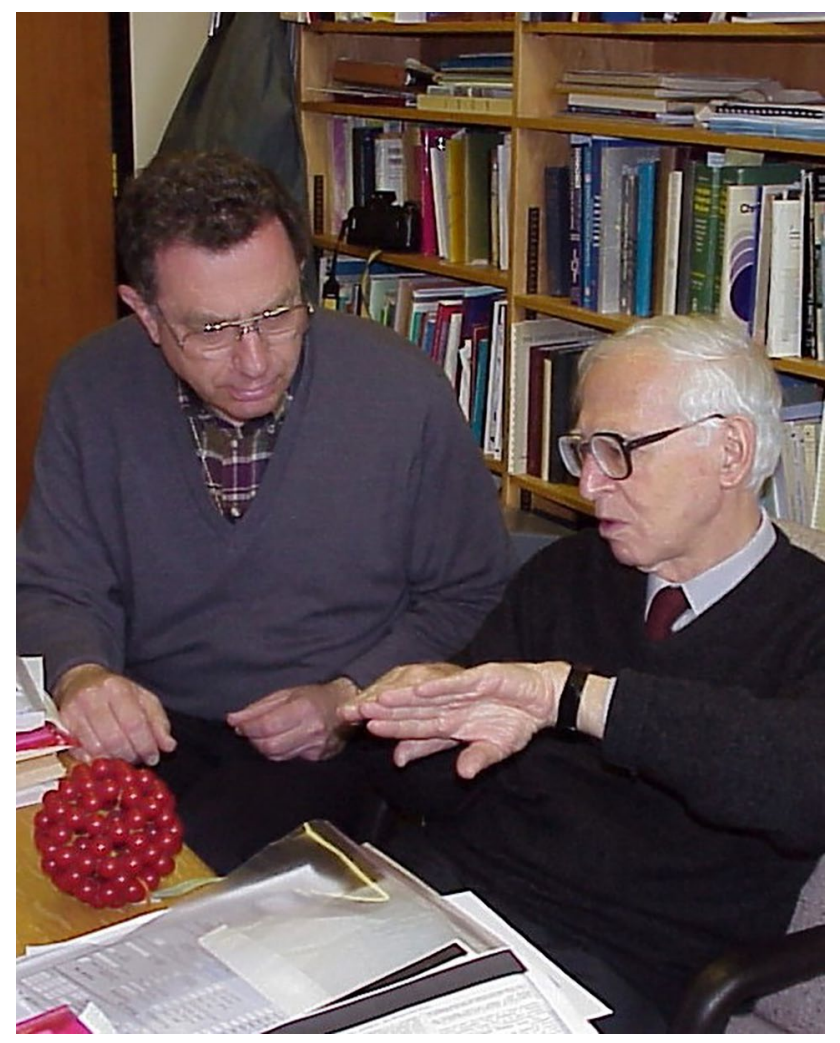

Fig. 11 Aaron Klug explaining to Istvan Hargittai, 2000, at the LMB (photograph by and (c) the Hargittais) reviewed and the results can reduce or increase our funding. So far, we have had a steady increase of our funding from MRC, and members of the Scientific Staff of LMB value its status as an MRC Laboratory [7].

Richard Henderson's award-winning research introduced the possibility of using the electron microscope to create a three-dimensional image of a protein at atomic resolution. The electron beam has important advantages over the X-rays, among them the close to million-fold stronger intensity of the interaction between matter and irradiation. This advantage causes problems as well, because the strong interactions may destroy the object whose structure needs to be elucidated. Our own research, in which the principal experimental technique has been electron diffraction, helped closeness to Henderson's interest, the overlap being in the utilization of electron beams in structure determination. This also related us to Aaron Klug's research interests.

Aaron Klug (Fig. 11) was a pioneer in electron crystallography and a pioneer in understanding the structure of viruses. The virus structures and their icosahedral symmetry in particular made it for us especially exciting to learn from Aaron Klug. At some point, Klug and Donald Caspar

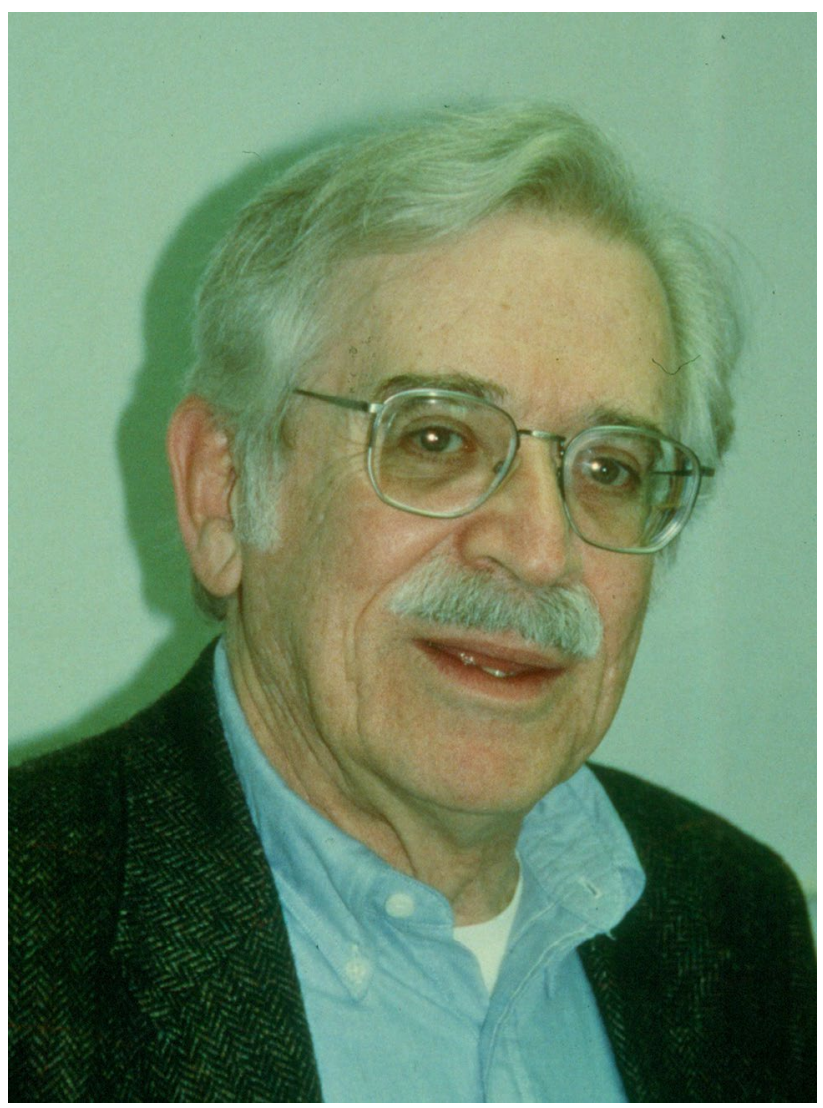

Fig. 12 Donald Caspar, 1996, in Tallahassee, Florida (photograph by and (c) the Hargittais) 


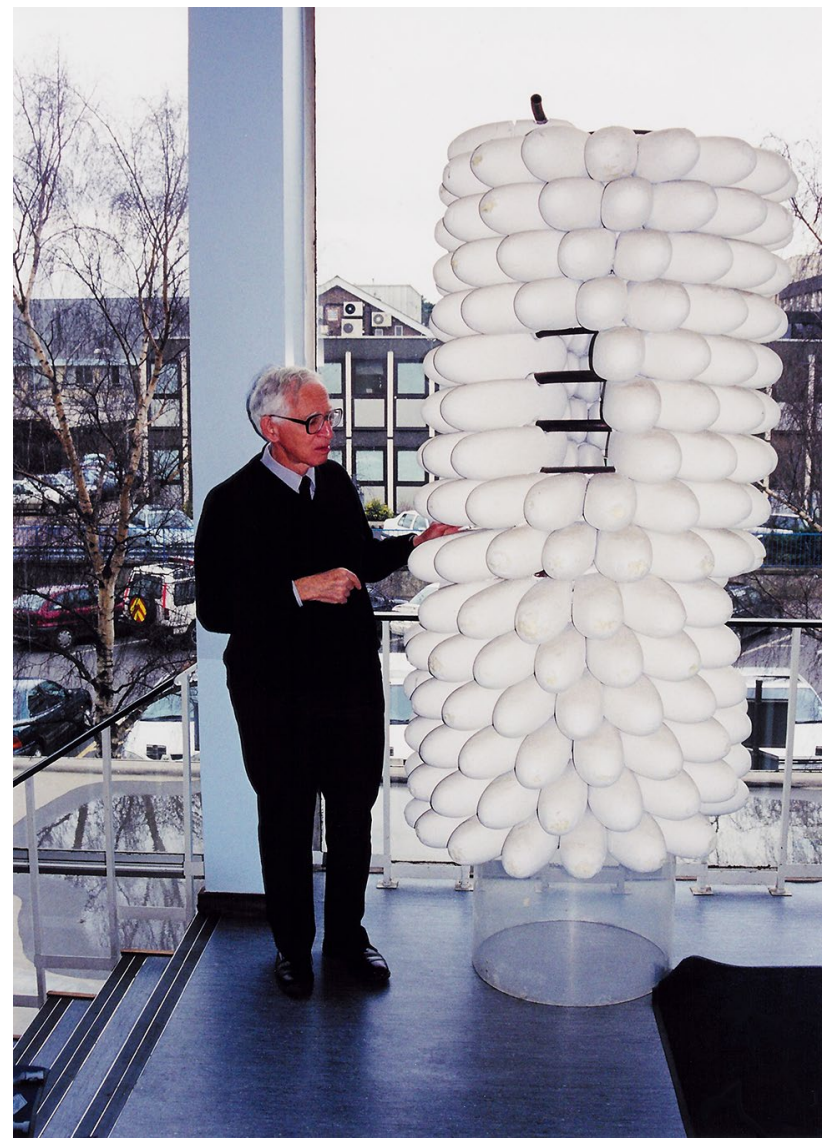

Fig. 13 Aaron Klug, 2000, with the tobacco mosaic virus model at the LMB (photograph by and (c) the Hargittais)

(Fig. 12), another future LMB alumnus, joined forces and made important discoveries about the structure of viruses. Caspar did his first X-ray diffraction study of viruses in 1955 in Cambridge and reported about icosahedral symmetry of their structures in 1956. Klug joined Rosalind Franklin in 1954 to work on virus structures at Birkbeck College in London and she obtained the first experimental data on the symmetry of the poliovirus. In 1962, Caspar and Klug published a seminal paper about the icosahedral virus structures [8]. Remarkably, the image of Buckminster Fuller's geodesic dome was one of the illustrations in their paper. Thus, for the first time, Caspar and Klug linked Fuller with chemical structures. We all know how important this link eventually became in the discovery of buckminsterfullerene. Fuller visited Birkbeck College as one of the many interesting people who came to see J. Desmond Bernal. In this case, however, Bernal was not too much interested in what Fuller had to say, but Klug was. This demonstrated Klug's broad interest and imagination as if anticipating the expansion of crystallography toward what has become known as generalized crystallography—the science of structures [9].
Our only longer stay at the MRC LMB was in 2000. The main question for us to answer was related to the comparison of accuracies in the structure determination of small gaseous molecules and the large biological molecules. We were not the only researchers who found this question timely. Recently, Durward Cruickshank published a paper in which he discussed the precision in protein structure determination [10]. He was a crystallographer with a good knowledge of gas-phase electron diffraction studies, but he limited his considerations in this paper to the solid state. We had a great deal of experience of the importance of accurate structure determination [11]. We had a preconception that in X-ray crystallography of biological molecules it was not possible, neither was it necessary, to reach similar degrees of accuracy as it was possible for small, free molecules. All what we learned at the LMB in 2000 proved our preconception wrong [12].

We learned a great deal from Aaron Klug about the structure of viruses, among others, and about the process leading to the discovery of their structure [13]. The model of the tobacco mosaic virus (TMV; Fig. 13) turned out to be attractive visually in addition to being a research achievement. It was the culmination of Klug's work with Rosalind Franklin in which Kenneth Holmes and John Finch also participated. It was decided to prepare the model of TMV for the 1958 world exhibition in Brussels. By the time the actual construction of the model was happening, Franklin was already in hospital and she died in 1958. When Klug wanted to start building the protein helix around the RNA rod, he realized a great difference between ordinary polymers and biological macromolecules. A polymer molecule is held together by strong bonds and its model could be begun at any point. The biological specificity of the biological macromolecules is determined by weak interactions and to observe its special sequence, it needs to begin with initiating nucleation. Klug did not find this initial nucleation at once, only following some failed attempts. He spoke about this in his Nobel lecture and he inserted an image demonstrating his initial idea of nucleation in his Nobel lecture for publication. He got into an argument with the editor of the collection of the Nobel lectures who wanted to cut the image out of the published version, because it was wrong. Klug protested and insisted on having the image included as it was an important ingredient of finally understanding the virus structure. To us, he quoted the philosopher A. N. Whitehead "It is more important that an idea be fruitful than that it be correct."

The MRC LMB is a research venue and one of its advantages for its associates is that they are not bogged down with teaching undergraduates. Yet it is also a great institution of higher education in the best meaning of this word. Its relatively small size, the intimacy, and the possibility of 
interacting with the greats of contemporary science contribute to its uniqueness in cultivating fledgling scientists.

Funding Open access funding provided by Budapest University of Technology and Economics.; Please verify relation to: Budapest University of Technology and Economics.

\section{Declarations}

Conflict of interest The authors declare no competing interests.

Open Access This article is licensed under a Creative Commons Attribution 4.0 International License, which permits use, sharing, adaptation, distribution and reproduction in any medium or format, as long as you give appropriate credit to the original author(s) and the source, provide a link to the Creative Commons licence, and indicate if changes were made. The images or other third party material in this article are included in the article's Creative Commons licence, unless indicated otherwise in a credit line to the material. If material is not included in the article's Creative Commons licence and your intended use is not permitted by statutory regulation or exceeds the permitted use, you will need to obtain permission directly from the copyright holder. To view a copy of this licence, visit http://creativecommons.org/licenses/by/4.0/.

\section{References}

1. Cochran V, Crick FHC, Vand V (1952) The structure of synthetic polipeptides. I. The transform of atoms on a helix. Acta Crystallogr A 5:581-586

2. Bragg WL, Kendrew JC, Perutz MF (1950) Polypeptide chain configurations in crystalline proteins. Proceedings of the Royal Society 203A:321-357

3. Hargittai I (2011) Drive and curiosity: what fuels the passion for science. Prometheus, Amherst, New York, Chapter 4, "Spirit of competition: Structure of proteins," pp 86-105
4. Hargittai I (2002) Candid science II: Conversations with famous biomedical scientists. Edited by M Hargittai, Imperial College Press, London, Chapter 22, “Sidney Altman," pp 338-349; actual quote, $\mathrm{p} 345$

5. Hargittai I (2011) Drive and curiosity: what fuels the passion for science. Prometheus, Amherst, New York, Chapter 5, "Valuing a steady job: Sequencing biopolymers," pp 106-122

6. Hargittai I (2002) Candid science II: Conversations with famous biomedical scientists. Edited by M Hargittai, Imperial College Press, London, Chapter 5, "Frederick Sanger," pp 72-83; actual quote, pp 76-78

7. Hargittai I (2002) Candid science II: Conversations with famous biomedical scientists. Edited by M Hargittai, Imperial College Press, London, Chapter 19, "Richard Henderson," pp 296-305; actual quote, $\mathrm{p} 304$

8. Caspar DLD, Klug A (1962) Physical principles in the construction of regular viruses. Cold Spring Harbor Symp Quant Biol 27:1-24

9. Hargittai I, Hargittai M (2000) In our own image: personal symmetry in discovery. Kluwer/Plenum, New York, etc

10. Cruickshank DWJ (1999) Remarks about protein structure precision. Acta Crystallographica D (Biological Crystallography) 55:583-601. Erratum, 55:1108

11. Domenicano A, Hargittai I (eds) (1991) Accurate molecular structures. Oxford University Press, Oxford, Their determination and importance

12. Hargittai M, Hargittai I (2002) Aspects of structural chemistry in molecular biology. In Domenicano A, Hargittai I, Editors, Strength from weakness: Structural consequences of weak interactions in molecules, supermolecules, and crystals. Kluwer Academic, Dordrecht, Boston, London, Chapter 6:91-119

13. Hargittai I (2002) Candid science II: Conversations with famous biomedical scientists. Edited by M Hargittai, Imperial College Press, London, Chapter 20, "Aaron Klug," pp 306-329; actual quote, p 313

Publisher's Note Springer Nature remains neutral with regard to jurisdictional claims in published maps and institutional affiliations. 